\title{
THE INFLUENCE OF COMPETENCE AND COMMUNICATION ON EMPLOYEE PERFORMANCE OF INTERNAL AUDIT WORK UNIT AT PT BANK MANDIRI (PERSERO), TBK WITH MEDIATING VARIABLE JOB SATISFACTION
}

\author{
Marwah Aya Shofia \\ Faculty of Economics, Universitas negeri Jakarta \\ Jakarta, Indonesia \\ marwah.ayashofia @gmail.com
}

\begin{abstract}
This study aims to analyze the influence of competence and communication on internal audit employees' performance at PT Bank Mandiri (Persero) Tbk with the mediating variable of Job Satisfaction. The population in this study were 284 employees of the internal audit of PT Bank Mandiri Tbk. Whereas in this study using saturated samples, the entire population of this study became research respondents. The data collection method is by distributing questionnaires as a primary data collection tool. Furthermore, the data is processed and analyzed using the Amoss 26 Structural Equation Models method. This study uses competency and communication independent variables as well as employee performance-dependent variables and job satisfaction mediation variables. The results of the study prove that there is an effect of competence on job satisfaction; there is an effect of communication on job satisfaction; there is an influence of competence on performance; there is an effect of communication on performance; there is an effect of job satisfaction on performance; there is an influence of competence on performance through job satisfaction; there is an effect of communication on performance through job satisfaction.
\end{abstract}

Keywords: Competence, Communication, Job Satisfaction, Employee Performance 
As one of the financial institutions that play a dominant role in the operation of the financial and banking service system, the performance of the bank can be an indicator that determines the rate of economic growth of a country because almost all economic activities are related to banking services. Apart from being an institution for the traffic and circulation of money, banks also play a role in assisting entrepreneurs in developing and improving their business. One of the functions of public banking services required by entrepreneurs is the provision of credit for business development and improvement. Bank Indonesia requires banks to have and implement an internal supervision system to ensure the implementation of a decision-making process in bank management according to the prudential principle. Considering that banks are associated with funds from the public, which are kept based on trust, each bank needs to maintain its health and maintain public trust. In this regard, banks are required to conduct business activities by the precautionary principle and maintain a soundness level by the following provisions: a) capital adequacy; b) asset quality; c) management quality; d) liquidity; e) profitability; and f) solvency.

It is known that the implementation of an internal control system to ensure the implementation of a decision-making process in bank management by the prudential principles is an obligation for every bank, including for Bank Mandiri. One of the functions of this internal control is carried out by Bank Mandiri by the Internal Audit Unit. Safeguarding business activities according to the vision and mission of PT Bank Mandiri (Persero) Tbk and providing a foundation and guidelines for Internal Audit (IA), which is part of the Internal Control System. It is necessary to establish an Internal Audit Charter (IAC). The Internal Audit Charter was prepared based on the Bank Indonesia Regulation regarding the implementation of the Bank Internal Audit Function Implementation Standards (SPFAIB) and the Decree of the Head of the Capital Market \& Financial Institutions Supervisory Agency concerning the Formation and Guidelines for the Preparation of the Internal Audit Unit Charter and standards from The Institute of Internal Auditors (IIA).

Given that the implementation of the internal supervisory function is deemed essential for the decision-making process in bank management by the prudential principles, it is inevitable that the management of Bank Mandiri must optimize the performance of the 
Internal Audit Unit. This work unit's performance depends on the performance of the employees serving in the Internal Audit Work Unit. Therefore, efforts to improve employee performance at the Internal Audit Work Unit of PT Bank Mandiri (Persero) Tbk deserve to be put forward as one of the strategic issues in developing banking performance.

On the internal side, Bank Mandiri has been implementing the third phase of the transformation program for one year, where one of the strategies is to strengthen the distribution network by integrating all business segments and subsidiaries. The implementation of this strategy poses many challenges in terms of infrastructure readiness, changes in work culture, and Human Resources' capabilities. Also, the internal side of the Internal Audit unit, namely the number of junior employees, is more than the number of senior employees, and this can affect job dissatisfaction for senior employees due to the high competence of new employees and good communication with the leadership so that an increase in the number of employees enters each time its year.

Employees' performance at the Internal Audit Work Unit of PT Bank Mandiri (Persero) Tbk needs to be improved to reach a reliable level. Efforts to enhance employee performance will achieve an expected level of success if the improvement efforts are made by considering the factors that affect employee performance. Thus, the performance of employees in the Internal Audit Unit is elevated to a phenomenon of individual performance that cannot be separated from the influence of various factors. Among the multiple factors that affect the performance of these employees, the authors assume that Competence and Communication are two factors that have a positive effect on Employee Performance at the Internal Audit Work Unit of PT Bank Mandiri (Persero) Tbk and with job satisfaction as the mediation of these two factors. To actualize these assumptions, the authors chose the following research title: "The Effect of Competence and Communication on Employee Performance of Internal Audit Work Unit at PT Bank Mandiri (Persero) Tbk with the Mediation Variable Job Satisfaction". The title of the research mentioned above was chosen because employee performance problems in the Internal Audit work unit of PT Bank Mandiri and their relationship with Competence and Communication can be appointed as the object of research to apply Economics, especially Human Resource Management. 


\section{LITERATURE REVIEW}

\section{Employee performance}

Organizational performance rests on the performance of individuals or members of the organization. How individual performance can be a determining factor for organizational performance can be learned from the concept of understanding performance described by Prawirosentono (1999: 1) as follows:

Performance is the work that can be achieved by a person or group of people in an organization, by their respective authorities and responsibilities, to achieve the goals of the organization concerned legally, does not violate the law, and is by morals and ethics. Levesque (Prawirosentono, 1999: 248) defines performance as "performance is we do and the result is produced by carrying out job functions", or what is done. The results achieved are made through the implementation of functions in work.

Gordon (1993: 14) said that "Performance was a function of employee's ability, acceptance of goals, level of the goals, and the interaction of the goal with their ability." Gordon's opinion shows that performance contains four things: Ability, Acceptance of organizational goals; The level of goals achieved; and the interaction between the goals and capabilities of the members of the organization.

Robbins (1996: 237) states that: "performance is the measurement of result, it asks the simple question did you get the job done." Another definition of performance is also expressed by Maier (in As'ad, 1995: 47), which says that performance is a person's success in carrying out a job.

Performance is the result of a person as a whole during a specific period in carrying out tasks, such as standard work results, targets, or target criteria that have been determined in advance and have been mutually agreed upon (Veithzal, 2005: 97). Employee performance is not just information for promotion or salary determination for the company. However, how the company can motivate employees and develop a plan to fix the decline in performance can be avoided. According to Munandar (2008: 287), performance appraisal is a process of assessing personality traits, work behavior, and the work results of a worker or employee (workers and managers), which are considered to support their work performance, which is used as consideration for making decisions about measures in the field of the workforce. 
According to Maltis and Jackson (2002), employee performance is how much they contribute to the organization, which includes:

1) The number of outputs that should be compared with actual capabilities.

2) Quality of production takes precedence over quantity

3) Provision of time used in producing an item. If the employee can shorten the processing time according to the standard, then the employee can be said to have a good performance.

4) The employee's attendance at the workplace has been determined at the beginning of the employee joining the company, if the employee's attendance is below the set working day standard, the employee will not be able to contribute optimally to the company

5) The involvement of all employees in achieving the targets set is essential that good cooperation between employees will improve performance.

Regarding indicators, according to Sutrisno (2009), performance measurement is directed at six aspects, namely:

1) Work results: the level of quantity and quality that has been produced and the extent to which supervision is carried out.

2) Job knowledge: the level of expertise associated with the job assignment directly affects the work's quantity and quality.

3) Initiative: the initiative level during work tasks, especially in terms of handling problems that arise.

4) Mental skills: the ability and speed of accepting work instructions and adapting to existing work methods and work situations.

5) Attitude: the level of morale and positive attitude in carrying out work tasks.

6) Discipline of time and attendance: level of punctuality and level of attendance

The description above, it can be synthesized that performance is the result of a person as a whole during a specific period in carrying out tasks, such as work standards, targets, or target criteria that have been determined in advance and have been mutually agreed upon (Veithzal, 2005: 97). The dimensions that will be used as indicators of performance variables are work results, job knowledge, initiative, mental skills, attitudes, and discipline.

\section{Job satisfaction}


According to Kreitner and Kinicki $(2001 ; 271)$, job satisfaction is "an effectiveness or emotional response to various aspects of work". Davis and Newstrom $(1985 ; 105)$ describe "job satisfaction as a set of employees' feelings about whether their job is fun or not". According to Robbins $(2003 ; 78)$, job satisfaction is "a general attitude towards a person's job that shows the difference between the amount of rewards employees receive and the amount they believe they should receive". Job satisfaction is an affective or emotional response to various aspects of a person's job, so that job satisfaction is not a single concept. A person can be relatively satisfied with one aspect of a job and dissatisfied with one or more other elements.

Job Satisfaction is a worker's (positive) attitude towards his job, which arises based on assessing the work situation. The assessment can be carried out on one of the jobs; the evaluation is carried out as a sense of appreciation in achieving one of the job's critical values. Satisfied employees prefer their work situation rather than dislike them. Feelings related to job satisfaction and dissatisfaction tend to reflect the worker's assessment of current and past work experiences rather than expectations for the future. So it can be concluded that there are two essential elements in job satisfaction: job values and basic needs. Work values are the goals to be achieved in doing work tasks. What you want to achieve are work values that are considered necessary by individuals. It goes on to say that work values must match or help fulfill basic needs. Thus, it can be concluded that job satisfaction is the result of workforce-related work motivation. Overall job satisfaction for an individual is the sum of job satisfaction (from each aspect of the job) multiplied by the degree of importance of that aspect of the individual's employment.

An individual will feel satisfied or dissatisfied with his work, which depends on how he perceives a match or contradiction between his desires and the results. So, it can be concluded that job satisfaction is a positive attitude of the workforce, including feelings and behavior towards their work through an assessment of one job as a sense of appreciation in achieving one of the important values of the job.

\section{Competence}

Competence correlates with performance because competence determines how a person does his job. In this context, David McClelland (in Martin, 2002: 151) says: 
There is something fundamental characteristic that is more important in predicting job success. That something is more valuable than academic intelligence. Something that can be determined accurately can be a critical factor differentiating between a star performer and deadwood. According to McClelland, that something is called: Competence.

Based on McClelland's thinking, it is clear that competence is one of the factors that distinguishes someone who can show optimal performance from someone unable to deliver optimal performance. Competence is a collection of human resources that dynamically indicates a person's intellectual capacity, mental attitude quality, and social capability.

Neo (2002) in Winanti (2012: 250) explains that competence is an aspect of a person's ability which includes knowledge, skills, attitudes, values, or personal characteristics that enable workers to achieve success in completing their work through achieving results or success in completing tasks.

Ainsworth et al. (2007: 73) say that competence is a combination of knowledge and skills that are relevant to work. Competence is the capacity to handle a job or task based on a predetermined standard.

Furthermore, Boulter et al. (1996) in Yunus Journal (2012: 372-373) explains that competence is a fundamental characteristic of a person that enables them to produce superior performance in their work. (Boulter et al., 1996). Based on this description, the meaning of competence contains a part of the personality that is deep and inherent in a person with predictable behavior in various circumstances and job assignments. The prediction of who will perform well and who will not perform well can be measured from the criteria or standards used.

\section{Communication}

One of the administrative activities in establishing cooperation between work units that connect individuals with individuals, connecting individuals with groups or work units, and connecting groups with the environment is a communication activity.

According to Rogers (in Sutarto, 1991: 8), "We defined communication as the process by which an idea is transferred from a source to a receiver to change his or her behavior". With this opinion, Rogers shows that communication is a process in which an idea is transferred from the source to the receiver to change its behavior. In this context, Wilbur 
Schram (in Sutarto, 1991: 9) says Communication is an act of establishing contact between a sender and receiver, with the help of a message; the sender and receiver some common experience which means to the message encode and sent by the sender, and received and decoded by the receiver.

Schram's opinion shows that communication is understood as making contact between sender and receiver, with the help of messages; Senders and recipients have some common experiences that give meaning to coded messages and send by the sender received and interpreted by the recipient. In this context, whether all contacts can be said to be a communication process and whether what distinguishes between connections is called communication or not.

\section{Theoretical Framework}

Based on the previous description, a research model can be prepared that describes the relationship between variables as follows:

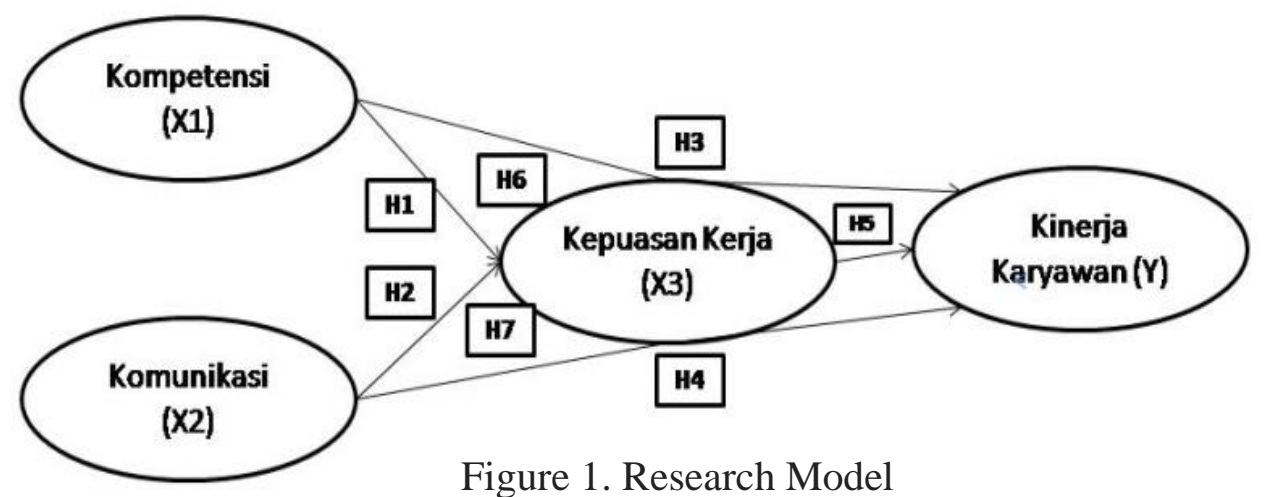

Based on the conceptual description, review of previous research, and the conceptual framework mentioned above, the hypotheses proposed in this study are as follows:

Hypothesis 1: Competence affects the Job Satisfaction of Internal Audit Employees at PT. Bank Mandiri (Persero) Tbk.

Hypothesis 2: Communication affects the Job Satisfaction of Internal Audit Employees at PT. Bank Mandiri (Persero) Tbk.

Hypothesis 3: Competence affects the Internal Audit Employee Performance at PT. Bank Mandiri (Persero) Tbk.

Hypothesis 4: Communication affects the Internal Audit Employee Performance at PT. Bank Mandiri (Persero) Tbk. 
Hypothesis 5: Job Satisfaction affects Internal Audit Employee Performance at PT. Bank Mandiri (Persero) Tbk.

Hypothesis 6: Competence affects Employee Performance which is intermediated by Internal Audit Job Satisfaction at PT. Bank Mandiri (Persero) Tbk.

Hypothesis 7: Communication affects Employee Performance which is intermediated by Internal Audit Job Satisfaction at PT. Bank Mandiri (Persero) Tbk.

\section{RESEARCH METHOD}

\section{Population and sample}

The population in this study were all employees of the Internal Audit of PT Bank Mandiri (Persero) Tbk, totaling 284 employees. Withdrawal of samples using saturated samples, then the entire population became the study sample, amounting to 284 respondents.

\section{Operational Definition}

The variables in this study are operationally defined as follows:

Table 1. Operational Research Definition

\begin{tabular}{|c|c|c|c|}
\hline $\begin{array}{l}\text { Variable } \\
\text { Types }\end{array}$ & Variable & Dimension & Indicator \\
\hline Dependent & Performance & $\begin{array}{l}\text { 1. Work Results } \\
\text { 2. Work Knowledge } \\
\text { 3. Initiative } \\
\text { 4. Mental Skills }\end{array}$ & $\begin{array}{l}10 \\
\text { Research } \\
\text { Indicator }\end{array}$ \\
\hline \multirow{3}{*}{ Independent } & Job Satisfaction & $\begin{array}{l}\text { 1. Own Work } \\
\text { 2. Relationship Bosses } \\
\text { 3. Friends at Work } \\
\text { 4. Promotion }\end{array}$ & $\begin{array}{l}10 \\
\text { Research } \\
\text { Indicator }\end{array}$ \\
\hline & Competency & $\begin{array}{ll}\text { 1. } & \text { Core } \\
\text { 2. } & \text { Function } \\
\text { 3. } & \text { Role } \\
\text { 4. } & \text { Work Model }\end{array}$ & $\begin{array}{c}\text { 10 } \\
\text { Research } \\
\text { Indicator }\end{array}$ \\
\hline & Communication & $\begin{array}{l}\text { 1. Control } \\
\text { 2. Motivation } \\
\text { 3. Information } \\
\text { 4. Expression } \\
\text { 5. Emotional }\end{array}$ & $\begin{array}{c}\text { 10 } \\
\text { Research } \\
\text { Indicator }\end{array}$ \\
\hline
\end{tabular}

\section{RESULT AND DISCUSSION}


The results of the model fit size can be seen in the following table: Table 2: Model Fit Size Results

Table 2. Model Fit Size Results

\begin{tabular}{|c|c|c|c|}
\hline $\begin{array}{c}\text { The } \\
\text { goodness of Fit } \\
\text { Index }\end{array}$ & $\begin{array}{c}\text { Cut-off } \\
\text { Value }\end{array}$ & $\begin{array}{c}\text { Default } \\
\text { Model }\end{array}$ & $\begin{array}{c}\text { Evaluation } \\
\text { Model }\end{array}$ \\
\hline Chi-Square & $\begin{array}{c}\text { The smaller, } \\
\text { the better }\end{array}$ & 18,644 & Good Fit \\
\hline Probability & $\geq 0,05$ & 0,051 & Good Fit \\
\hline CMIN/DF & $\leq 2,00$ & 1,606 & marginal Fit \\
\hline GFI & $\geq 0,90$ & 0,873 & Good Fit \\
\hline AGFI & $\geq 0,90$ & 0,911 & Good Fit \\
\hline TLI & $\geq 0,90$ & 0,963 & marginal Fit \\
\hline CFI & $\geq 0,90$ & 0,872 & Good Fit \\
\hline RMSEA & $\leq 0,08$ & 0,02 & \\
\hline
\end{tabular}

Source: Results of Data Processing (2019)

The model construct test results are presented in Table 2 above and evaluated based on the fit indices' goodness. The criteria for the model and the standard that has the data's suitability can be seen in table 2 . The following is a summary of the results of the goodness of fit test after modification:

1) Chi-square value is 18.644 with the recommended significant level of acceptance is $p>$ 0.05 , the chi-square value decreases after modification. Based on the research results, it was obtained that the chi-square was 13.644, so the model was declared a good fit.

2) The probability value is 0.051 , which is greater with a cut-off value of $>0.05$, so the model is declared a good fit.

3) The CMIN / DF value is 1.606 smaller with a cut-off value of $<2.00$, so the model is declared a good fit.

4) The GFI value is 0.873 , more or less with a cut-off value of $>0.90$, so the model is declared marginal fit. 
5) AGFI value is greater than 0.911 with a cut-off value $>0.90$, so the model is told a good fit.

6) The TLI value is 0.963 , which is greater with a cut-off value $>0.90$, so the model is declared a good fit.

7) The CFI value is 0.872 more or less with a cut-off value $>0.90$, so the model is declared marginal fit.

8) The RMSEA value is greater than 0.02 with a cut-off value $<0.08$, so the model is declared a good fit.

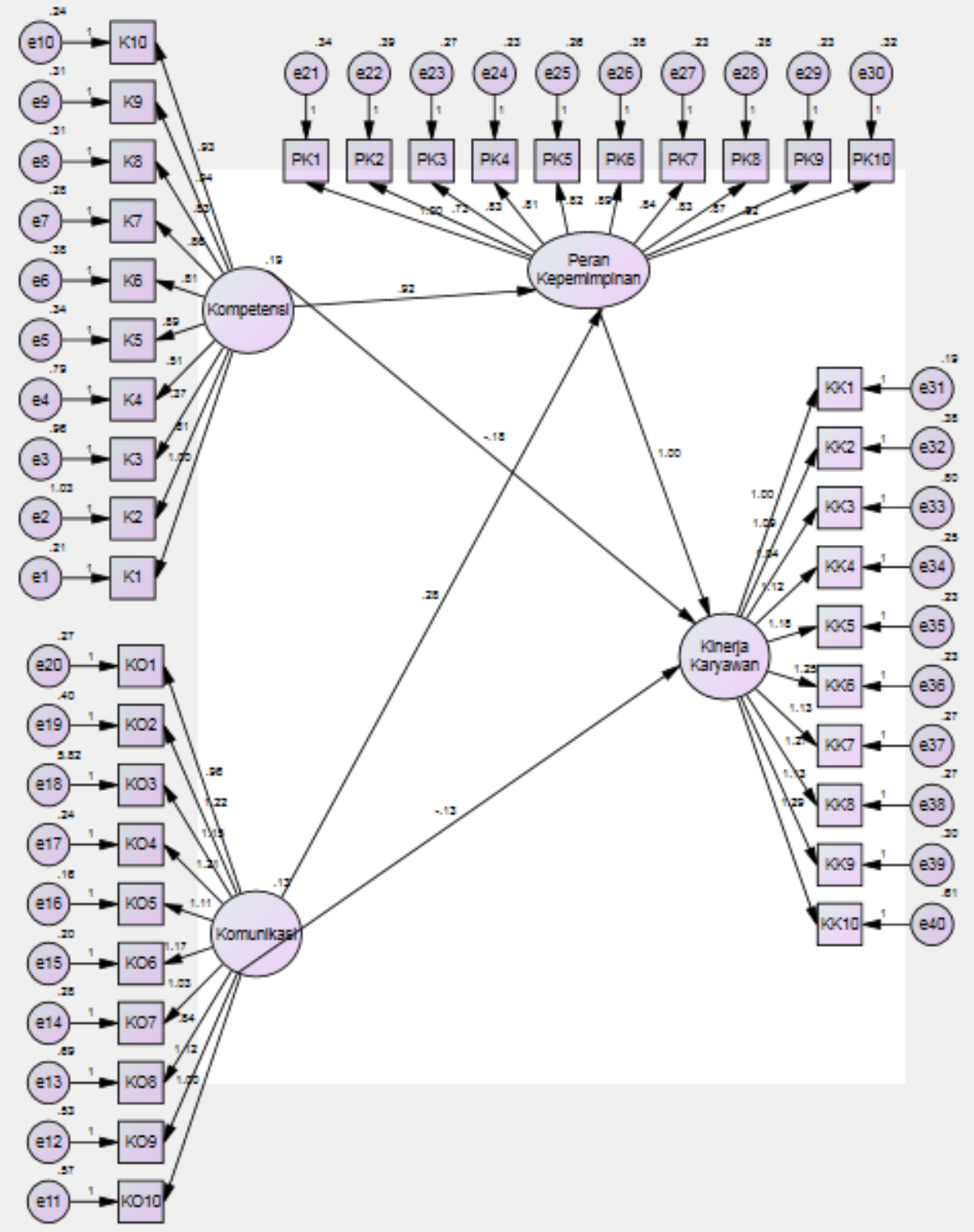

Figure 2. Estimation Results of the Output Model

\section{Structural Model Analysis}


The structural model analysis relates to coefficients or parameters that show the effect of the relationship between latent variables on other latent variables. The following is a table of regression weights from the results of structural model research.

Table 3. Tabel Regression Weight

\begin{tabular}{|c|c|c|c|c|c|c|c|}
\hline & & & Estimate & S.E. & C.R. & $\mathrm{P}$ & Label \\
\hline PK & $<-$ & $\mathrm{K}$ & -.447 & .127 & 3.524 & $* * *$ & par_25 \\
\hline PK & $<-$ & Ko & -.402 & .095 & 2.015 & .001 & par_26 \\
\hline KK & $<$ & $\mathrm{K}$ & 1.166 & .111 & 10.519 & $* * *$ & par_27 \\
\hline KK & $\begin{array}{l}<- \\
--\end{array}$ & Ko & .348 & .128 & 2.732 & .001 & par_28 \\
\hline KK & $\begin{array}{ll}<- \\
--\end{array}$ & PK & .496 & .051 & 9.733 & $* * *$ & par_29 \\
\hline KK & $<-$ & $\mathrm{K}, \mathrm{PK}$ & 1.000 & .071 & 3.412 & $* * *$ & par_29 \\
\hline Q4 & $\begin{array}{ll}<- \\
--\end{array}$ & Ко,PK & .808 & .144 & 5.598 & $* * *$ & par_1 \\
\hline
\end{tabular}

Source: Results of Data Processing (2019)

Based on the table above, the hypothesis obtained is as follows:

Table 3 above is used as the primary reference for conducting hypothesis testing in this study. The test criterion is HO reject if the Critical Value CR is 1.967 or the p-value is less than 0.05 . The results of testing all hypotheses in this study are as follows:

1) Hypothesis Testing 1

Effect of Competence on Job Satisfaction

Ho: Competence does not affect job satisfaction

Ha: Competence affects the job satisfaction

Result: The value of C.R. of 3.524> 1.967 and the p-value of $0.00<0.05$

Then Ha is accepted so that it can be concluded that direct evidence of competence affects the job satisfaction

2) Hypothesis Testing 2

Effect of Communication on Job Satisfaction

Ho: Communication does not affect job satisfaction

Ha: Communication affects the job satisfaction 
Result: The value of C.R. amounting to 2.015> 1.967 and the p-value of $0.001<0.05$ Then $\mathrm{Ha}$ accepted so that it can be concluded that communication affects the job satisfaction

3) Hypothesis Testing 3

Effect of Competence on Employee Performance

Ho: competence does not affect employee performance

Ha: competence affects employee performance

Result: The value of C.R. amounting to 10,519>1,967 and the p-value of $0.00<0.05$

Then $\mathrm{Ha}$ is accepted so that it can be concluded that competence affects employee performance

4) Hypothesis Testing 4

The Influence of Communication on the Role of Employee Performance

Ho: Communication does not affect employee performance

Ha: Communication affects employee performance

Result: The value of C.R. of 2.7> 1.967 and the p-value of $0.01<0.05$

Then $\mathrm{Ha}$ is accepted so that it can be concluded that communication affects employee performance.

5) Hypothesis Testing 5

The Effect of Job Satisfaction on Employee Performance

Ho: Job satisfaction does not affect employee performance.

Ha: Job satisfaction affects employee performance

Result: The value of C.R. amounting to 9.7> 1,967 and the p-value of $0.00<0.05$

Then $\mathrm{Ha}$ is accepted so that it can be concluded that job satisfaction affects employee performance.

6) Hypothesis Testing 6

The influence of competence on employee performance through job satisfaction Ho: no Effect of competence on employee performance through job satisfaction Ha: The influence of competence on employee performance through job satisfaction Result: The value of C.R. 3,412> 1,967 and p-value of $0.00<0.05$

Then Ha accepted so that it can be concluded that the influence of competence on employee performance through job satisfaction. 
7) Hypothesis Testing 7

The influence of communication on employee performance through job satisfaction Ho: no Effect of communication on employee performance through job satisfaction Ha: The influence of communication on employee performance through job satisfaction Result: The value of C.R. 3,412> 1,967 and p-value of $0.00<0.05$

Then Ha accepted so that it can be concluded that the influence of competence on communication through job satisfaction.

The research results presented above can be seen briefly in table 4 below:

Table 4. Hypotheses Summary

\begin{tabular}{|c|c|c|c|c|c|}
\hline Variable & $\mathbf{T}$-score & t-table & $\begin{array}{l}\quad \text { Ha } \\
\text { accepted if } \\
\text { significance } \\
t_{\text {score }}>t_{\text {table }}\end{array}$ & $\begin{array}{l}\text { Result } \\
\text { Testing }\end{array}$ & \\
\hline $\begin{array}{l}\text { Competence on Job } \\
\text { Satisfaction }\end{array}$ & 3,524 & 1,967 & $\mathrm{t}_{\text {score }}>\mathrm{t}_{\text {table }}$ & $\begin{array}{l}\text { Has } \\
\text { significant } \\
\text { effect }\end{array}$ & $\mathrm{a}$ \\
\hline $\begin{array}{l}\text { Communication on } \\
\text { Job Satisfaction }\end{array}$ & 2,015 & 1,967 & $t_{\text {score }}>t_{\text {table }}$ & $\begin{array}{l}\text { Has } \\
\text { significant } \\
\text { effect }\end{array}$ & $\mathrm{a}$ \\
\hline $\begin{array}{l}\text { Competence on } \\
\text { Performance }\end{array}$ & 10,519 & 1,967 & $t_{\text {score }}>t_{\text {table }}$ & $\begin{array}{l}\text { Has } \\
\text { significant } \\
\text { effect }\end{array}$ & $\mathrm{a}$ \\
\hline $\begin{array}{l}\text { Communication on } \\
\text { Performance }\end{array}$ & 2,732 & 1,967 & $t_{\text {score }}>t_{\text {table }}$ & $\begin{array}{l}\text { Has } \\
\text { significant } \\
\text { effect }\end{array}$ & $\mathrm{a}$ \\
\hline $\begin{array}{l}\text { Job Satisfaction on } \\
\text { Performance }\end{array}$ & 9.733 & 1,967 & $\mathrm{t}_{\text {score }}>\mathrm{t}_{\text {table }}$ & $\begin{array}{l}\text { Has } \\
\text { significant } \\
\text { effect }\end{array}$ & $\mathrm{a}$ \\
\hline $\begin{array}{ll}\text { Competence } & \text { on } \\
\text { Performance } & \\
\text { through } & \text { Job } \\
\text { Satisfaction } & \end{array}$ & 3.412 & 1,967 & $t_{\text {score }}>t_{\text {table }}$ & $\begin{array}{l}\text { Has } \\
\text { significant } \\
\text { effect }\end{array}$ & $\mathrm{a}$ \\
\hline $\begin{array}{l}\text { Communication on } \\
\text { Performance } \\
\text { through Job } \\
\text { Satisfaction }\end{array}$ & 3.412 & 1,967 & $\mathrm{t}_{\text {score }}>\mathrm{t}_{\text {table }}$ & $\begin{array}{l}\text { Has } \\
\text { significant } \\
\text { effect }\end{array}$ & $\mathrm{a}$ \\
\hline
\end{tabular}




\section{Effect of Competence on Internal Audit Job Satisfaction at PT Bank Mandiri (Persero) Tbk}

The results showed that there was an influence between the Competency variable on the Job Satisfaction variable. This decision was seen from the research results, which proved that the t-table value was greater than $t(3.524>1.96)$. The influence between competence and job satisfaction variables looks significant. This can be seen from the research results of the Sig equal to 0.000, which is smaller than the sig value. 0.05.

The influence between the Competency Variable and the Job Satisfaction Variable shows a causal relationship, which means that if the Competence of Internal Audit Employees at PT. Bank Mandiri (Persero) Tbk increased, the rise also followed this increase in Job Satisfaction of the Auditor of PT. Bank Mandiri (Persero) Tbk. Competency enhancement described can be done by improving the four dimensions of research that have been carried out, namely the core competency model, function, role, and work competency model.

\section{The Influence of Communication on Job Satisfaction of Internal Audit at PT Bank Mandiri (Persero) Tbk}

The results showed that there was an influence between the Communication variable on the Job Satisfaction variable. This decision was seen from the research results, which proved that the t-table value was greater than $t$ (2.015> 1.96). The influence between Communication and Job Satisfaction Variables looks significant. This can be seen from the research results of the Sig equal to 0.001, which is smaller than the sig value. 0.05.

The influence between the Communication Variable and the Job Satisfaction Variable shows a causal relationship, which means that if the Internal Audit Employee Communication at PT. Bank Mandiri (Persero) Tbk increased, an increase also followed this increase in Job Satisfaction of the Auditor of PT. Bank Mandiri (Persero) Tbk. Improved communication that is pictured can be done by increasing the four dimensions of research that have been carried out, namely Control; Motivation; Emotional expression; Information.

The Effect of Competence on the Performance of Internal Audit Employees at PT Bank Mandiri (Persero) Tbk 
The results showed that there was an influence between the competency variable on the employee performance variable. This decision was seen from the research results, which proved that the t-table value was greater than $t(10.519>1.96)$. The Influence between Competence and Performance Variables of Internal Audit Employees at PT. Bank Mandiri (Persero) Tbk looks significant; this can be seen from the research results of the Sig. equal to 0.000, which is smaller than the sig value. 0.05.

The influence between Competency Variables and Internal Audit Employee Performance Variables at PT. Bank Mandiri (Persero) Tbk shows a causal relationship, which means that if the Internal Audit Employee Competence at PT. Bank Mandiri (Persero) Tbk increased, also followed by an increase in the Internal Audit Employee Performance at PT. Bank Mandiri (Persero) Tbk. Competency enhancement described can be done by improving the four dimensions of research that have been carried out, namely the core competency model, function, role, and work competency model.

\section{The Influence of Communication on the Performance of Internal Audit Employees at PT Bank Mandiri (Persero) Tbk}

The results showed that there was an influence between the Communication variable on the Employee Performance variable. This decision was seen from the research results, which proved that the $\mathrm{t}$-table value was greater than $\mathrm{t}(2.732>1.96)$. The Influence of Communication with Internal Audit Employee Performance Variables at PT. Bank Mandiri (Persero) Tbk looks significant; this can be seen from the research results of the Sig. equal to 0.001 , which is smaller than the sig value. 0.05 .

The influence between Communication Variables and Internal Audit Employee Performance Variables at PT. Bank Mandiri (Persero) Tbk shows a causal relationship, which means that if the Internal Audit Employee Communication at PT. Bank Mandiri (Persero) Tbk increased, this increase was also followed by an increase in the Internal Audit Employee Performance at PT. Bank Mandiri (Persero) Tbk. Competency enhancement pictured can be done by increasing the four dimensions of research that have been carried out, namely control; Motivation; Emotional expression; Information.

The Effect of Job Satisfaction on the Performance of Internal Audit Employees at PT Bank Mandiri (Persero) Tbk 
The results showed that there was an influence between the Job Satisfaction variable on the Employee Performance variable. This decision was seen from the research results, which proved that the $t$-table value was greater than $t(9,733>1.96)$. The Influence of Communication with Internal Audit Employee Performance Variables at PT. Bank Mandiri (Persero) Tbk looks significant; this can be seen from the research results of the Sig. equal to 0.000 , which is smaller than the sig value. 0.05 .

The influence between Job Satisfaction Variables and Internal Audit Employee Performance Variables at PT. Bank Mandiri (Persero) Tbk shows a causal relationship, which means that Internal Audit Employees' Job Satisfaction at PT. Bank Mandiri (Persero) Tbk increased. This increase was also followed by an increase in the Internal Audit Employee Performance at PT. Bank Mandiri (Persero) Tbk. The increase in Job Satisfaction as described can be done by increasing the four dimensions of research that have been carried out, namely the work itself (work itself), relationship with superiors (supervision), workmates (workers), and promotion.

The Effect of Competence on Employee Performance Intermediated with Internal Audit Job Satisfaction at PT Bank Mandiri (Persero) Tbk

The results showed an influence between the competency variable on the employee performance variable mediated by the job satisfaction variable. This decision was seen from the research results, which proved that the t-table value was greater than $t(3,412>$ 1.96). The Influence between Competence and Performance Variables of Internal Audit Employees at PT. Bank Mandiri (Persero) Tbk, which is intermediated by the Job Satisfaction variable looks significant; this can be seen from the research results of the Sig. equal to 0.000 , which is smaller than the sig value. 0.05 .

The influence between Competency Variables and Internal Audit Employee Performance Variables at PT. Bank Mandiri (Persero) Tbk, which is intermediated by the Job Satisfaction variable shows a causal relationship, which means that if the Internal Audit Employee Competence at PT. Bank Mandiri (Persero) Tbk which is intermediated by the increased Job Satisfaction variable, this increase is also followed by an increase in the Performance of Internal Audit Employees at PT. Bank Mandiri (Persero) Tbk. The competency improvement described can be done by increasing the four dimensions of research that have been carried out, namely the core competency model, functions, roles, 
and work competency models, as well as by increasing the four dimensions of the Job Satisfaction variable, namely the work itself, the relationship with superiors (supervision), workers and promotion.

\section{Influence of Communication affects Employee Performance which is intermediated by} Internal Audit Job Satisfaction at PT Bank Mandiri (Persero) Tbk

The results showed an influence between the Communication variable on the Employee Performance variable, which was mediated by the Job Satisfaction variable. This decision was seen from the research results, which proved that the t-table value was greater than $t$ (5,598> 1.96). The Influence of Communication with Internal Audit Employee Performance Variables at PT. Bank Mandiri (Persero) Tbk, which is intermediated by the Job Satisfaction variable looks significant. This can be seen from the research results of the Sig. equal to 0.000 , which is smaller than the sig value. 0.05 .

The influence between Communication Variables and Internal Audit Employee Performance Variables at PT. Bank Mandiri (Persero) Tbk, which is intermediated by the Job Satisfaction variable, shows a causal relationship, which means that if the Internal Audit Employee Communication at PT. Bank Mandiri (Persero) Tbk which is intermediated by the increased Job Satisfaction variable, this increase is also followed by an increase in the Performance of Internal Audit Employees at PT. Bank Mandiri (Persero) Tbk. Improved communication described can be done by improving the four dimensions of research that have been done, namely control; Motivation; Emotional expression; Information, and also by increasing the four dimensions of the Job Satisfaction variable, namely the work itself, relationship with superiors (supervision), co-workers (workers) and promotion.

\section{CONCLUSION}

\section{Conclusion}

Based on the results of the research and discussion, the authors can provide the following conclusions:

1. There is an influence of Competence on Internal Audit Job Satisfaction at PT Bank Mandiri (Persero) Tbk, the results can be seen from the value of CR of 3.524>1.967 and the p-value of $0.00<0.05$. Then $\mathrm{Ha}$ is accepted so that it can be concluded that direct evidence of competence affects job satisfaction; 
2. There is an influence of Communication on Internal Audit Job Satisfaction at PT Bank Mandiri (Persero) Tbk, the value of CR amounting to 2.015> 1.967 and the p-value of $0.001<0.05$. So, Ha accepted so that it can be concluded that communication affects job satisfaction;

3. There is an influence of competence on the performance of internal audit employees at PT Bank Mandiri (Persero) Tbk, the value of CR amounting to 10,519> 1,967 and the pvalue of $0.00<0.05$. So Ha is accepted so that it can be concluded that competence affects employee performance;

4. There is an influence of communication on the Performance of Internal Audit Employees at PT Bank Mandiri (Persero) Tbk, the value of CR of 2.7> 1.967 and the pvalue of $0.01<0.05$. So, Ha is accepted so that it can be concluded that communication affects employee performance;

5. There is an influence of Job Satisfaction on the Performance of Internal Audit Employees at PT Bank Mandiri (Persero) Tbk, the value of CR amounting to 9.7> 1,967 and the p-value of $0.00<0.05$. Then $\mathrm{Ha}$ is accepted so that it can be concluded that job satisfaction affects employee performance;

6. There is an influence of competence on Employee Performance which is intermediated by Internal Audit Job Satisfaction at PT Bank Mandiri (Persero) Tbk, the value of CR $3,412>1,967$ and p-value of $0.00<0.05$. Then Ha accepted so that it can be concluded that the influence of competence on employee performance through job satisfaction

7. There is an effect of communication influencing Employee Performance which is intermediated by Internal Audit Job Satisfaction at PT Bank Mandiri (Persero) Tbk, the value of CR 3,412> 1,967 and p-value of $0.00<0.05$. Then Ha accepted so that it can be concluded that the influence of competence on communication through job satisfaction.

\section{Suggestion}

Based on the discussion and conclusions obtained from the discussion of the research results, the following suggestions are presented:

1. Increasing Job Satisfaction can be done by increasing the Competence of Internal Audit Employees at PT Bank Mandiri (Persero) Tbk, namely by increasing the core competency model, functions, roles, and work competency models; 
2. Increasing Employee Job Satisfaction can be done by improving the communication of each Internal Audit employee at PT Bank Mandiri (Persero) Tbk, namely by increasing Control; Motivation; Emotional expression; Information;

3. Improved Employee Performance Internal Audit of PT Bank Mandiri (Persero) Tbk can be improved by increasing Competence, Communication and Job Satisfaction of Employees. By improving the core competency model, function, role and work competency model, control; Motivation; Emotional expression; Information, work itself, relationship with superiors (supervision), co-workers (workers) and promotion.

\section{References}

Andayani, Dwi. (2018). Pengaruh Motivasi Kerja, Gaya Kepemimpinan Dan Budaya Organisasi Terhadap Kinerja Karyawan BPR Di Kabupaten Tulungagung Dalam Perspektif Islam. Inovatif. 4 (1): 2598-3172.

Basit, Abdul., Veronica Sebastian., Zubair Hassan. (2017). Impact of Leadership Style on Employee Performance (A Case Study on A Private Organization in Malaysia). International Journal of Accounting \& Business Management. 5 (2): 2289-4519.

Budianto, A.Aji Tri dan Amelia Katini. (2015). Pengaruh Lingkungan Kerja Terhadap Kinerja Pegawai pada PT Perusahaan Gas Negara (PERSERO) Tbk SBU Distribusi Wilayah I Jakarta. Jurnal Ilmiah Prodi Manajemen Universitas Pamulang. 3 (1).

Busro, Dr. Muhammad. (2018). Teori-Teori Manajemen Sumber Daya Manusia, Prenada Media.

Dewi, Cokorda Istri Ari Sintya, dan Imade Artha Wibawa. (2016). Pengaruh Stress Kerja dan Motivasi Kerja Terhadap Kinerja Karyawan Pada PT. Bank BPD Bali Cabang Ubud. E-Jurnal Manajemen Unud. 5 (12) 7583-7606.

Ermawati, Juni., Ardiani Ika Sulistyawati. (2014). Pengaruh Budaya Organisasi, Motivasi, Dan Kompensasi Terhadap Kinerja Karyawan Melalui Komitmen Organisasi Pada CV. Sampurno Abadi. Performance. 19 (1), Maret 2014.

Farizki, Muchamad, Ressa., Wahyuati Aniek. (2017). Pengaruh Motivasi Kerja dan Lingkungan Kerja Terhadap Kinerja Karyawan Medis. Jurnal Ilmu dan Riset Manajemen. 6 (5). 
Gardjito, Aldo Herlambang., Mochammad Al Musadieq., Gunawan Eko Nurtjahjono. (2014). Pengaruh Motivasi Kerja dan Lingkungan Kerja Terhadap Kinerja Karyawan (Studi Pada Karyawan Bagian Produksi PT. Karmand Mitra Andalan Surabaya. Jurnal Administrasi Bisnis (JAB). 13 (1).

Ghozali, Imam. (2009). Aplikasi Analisis Multivariate Dengan Program SPSS, UNDIP, Semarang. (2012). Aplikasi Analisis Multivariate Dengan Program IBM SPSS, UNDIP, Semarang.

Hameed, Abdul., Muhammad Ramzan., Hafiz M. Khasif Zubair. Ghazanfar Ali. (2014). Impact of Compensation on Employee Performance (Empirical Evidence from Banking Sector of Pakistan). International Journal of Business and Social Science. 5 (2), 2014.

Hardian, Ferry., Kusdi Rahardjo., Moch. Soe’oed Hakam. (2015). Pengaruh Gaya Kepemimpinan Terhadap Kinerja Karyawan (Studi Pada Karyawan Tetap Service Center Panasonic Surabaya). Jurnal Administrasi Bisnis (JAB), Vol. 1, No. 1, Januari 2015.

Hasibuan, S.P Malayu. (2005). Manajemen Sumber Daya Manusia, Edisi Revisi, Bhumi Aksara, Jakarta.

Heider, Fritz. (1958). The Psychology of Interpersonal Relations. New York: Wiley.

Josephine, Audrey., Dhyah Harjanti. (2017). Pengaruh Lingkungan Kerja Terhadap Kinerja Karyawan Pada Bagian Produksi Melalui Motivasi Kerja Sebagai Variabel Intervening Pada PT. Trio Corporate Plastic (Tricopla). AGORA. 5 (3).

Khotimah, Risfatul., Edward Gagah., Leonardo B Hashiolan. (2017). Pengaruh Kepemimpinan, Stress Kerja, dan Lingkungan Kerja Terhadap Kinerja Karyawan Produksi di PT. Ungaran Sari Garment. Jurnal of Management. $3(3)$.

Kwarimah, Annisa Coriyani., Dudung Abdurrahman., Ifa Hanifa Senjiati. (2018). Pengaruh Gaya Kepemimpinan Terhadap Kinerja Karyawan Pada Panin Dubai Syariah Bank KCU Asia Afrika Kota Bandung. Prosiding Keuangan dan Perbankan Syariah. 4 (1). 
Langi, Stifan R., Ddavid P. E. Saerang., Frederik G. Worang. (2015). The Impact Of Leadership Style, Work Motivation, And Job Satisfaction On Employee Performance (Bank BNI Kawangkoan Branch). Jurnal Berkala Ilmiah Efisiensi. 15 (05).

Leonardo, Edrick, Fransisca Andreani. (2015). Pengaruh Pemberian Kompensasi Terhadap Kinerja Karyawan Pada PT. Kapanitia. AGORA. 3 (2).

Mahpudin, Endang., Pupung Purnamasari. (2018). Pengaruh Motivasi Kerja Terhadap Kinerja Karyawan Pada PT. Bank Central Asia, Tbk Cabang Karawang. Jurnal Edunomic. 6 (2).

Mamesah, Andrew M.C., Lotje Kawet., Victor P.K Lengkong. (2016). Pengaruh Lingkungan Kerja, Disilin Kerja, dan Loyalitas Kerja Terhadap Kinerja Karyawan Pada LPP RRI Manado. Jurnal EMBA. 4 (3): 600-611.

Martinus, Erik., Budiyanto. (2016). Pengaruh Kompensasi Dan Motivasi Kerja Terhadap Kinerja Karyawan Pada PT. Devina Ssurabaya. Jurnal Ilmu Dan Riset Manajemen. 5 (1): 2461-0593.

Murti dan Hudiwinarsih. (2012). Pengaruh Kompensasi, Motivasi dan Komitmen Organisasional Terhadap Kinerja Karyawan Bagian Akuntansi (Studi Kasus Pada Perusahaan Manufaktur di Surabaya). The Indonesian Accounting Review. $2(2)$.

Nitasari, Rina., Sudarsih. (2016). Pengaruh Motivasi, Lingkungan Kerja dan Kompensasi Terhadap Kinerja Karyawan Pada Asuransi Jiwa Bersama (AJB) Bumi Putera 1912 Jember. Artikel Ilmiah Mahasiswa.

Njoroge, Sheila Wambui., Josephat Kwasira. (2015). Influence Of Compensation and Reward on Performance and Reward on Perfomance of Employees at Nakuru County Government. IOSR Journal of Business and Management (IOSRJBM). 17 (11), November 2015.

Nugroho, Restu Adi., Sri Hartono., Sudarwati. (2016). Pengaruh Komitmen Organisasi, Motivasi Berprestasi dan Gaya Kepemimpinan Terhadap Kinerja Karyawan PT. Wangsa Jatra Lestari. Jurnal Bisnis dan Ekonomi (JBE). 23 (2).

Prastyo, Eko., Leonardo Budi Hasiolan., Moh. Mukeri Warso., (2016). Pengaruh Motivasi, Kepuasan, dan Lingkungan Kerja Terhadap Kinerja Karyawan 
Honorer Dinas Bina Marga Pengairan dan ESDM Kabupaten Jepara. Journal Of Management. 2 (2).

Prawirosentono, Suyadi. (1999). Kebijakan Kinerja Karyawan. Edisi Pertama. Yogyakarta.

Putra, Febri Arifin., Mochammad Al Musadieq., Yuniadi Mayowan. (2016). Pengaruh Gaya Kepemimpinan dan Lingkungan Kerja Terhadap Kinerja Karyawan (Studi Pada Karyawan Perusahaan Daerah Air Minum (PDAM) Kota Malang). Jurnal Administrasi Bisnis (JAB). 40 (2).

Qatmeemalmarhoon, Ahmed Bin Ali Said., Khairrunneezam Bin Mohdnoor, Marai.A.D.Abdalla., Ali Ramadan Musbah. (2017). Effect of Motivation on Employees Performance and Employees Commitment. International Journal of Management and Apptied Science. 3 (9), September 2017.

Rahmawanti, Nela Pima., Bambang Swasto., Arik Prasetya. (2014). Pengaruh Lingkungan Kerja Terhadap Kinerja Karyawan (Studi Pada Karyawan Kantor Pelayanan Pajak Pratama Malang Utara). Jurnal Administrasi Bisnis (JAB). 8 (2).

Riana, Nova., Khoirul fajri, dan Karin Alsyaumi. (2016). Pengaruh Kompensasi Terhadap Kinerja Karyawan. Jurnal Tourism Scientific. Vol. 2.

Rivai, Veitzal. (2005). Manajemen Sumber Daya Manusia. Jakarta: PT. Raja Grafindo Persada.

Robbin, P. Stephen. (2009). Organizational Behaviour. 9 Edition. New Jersey: Precentice Hall International Inc.

Rukmini. (2016). Pengaruh Kompensasi dan Lingkungan Kerja Terhadap Kinerja Karyawan Pada CV. Roda Jati Karanganyar Tahun 2016. Jurnal Akuntansi dan Pajak. 17 (02): 49-60.

Samson, Gitahi Njenga., Maina Waiganjo., Joel Koima. (2015). Effect of Workplace Environment on the Perfomance of commercial Bank Employees in Nakuru Town. International Journal of Managerial Studies and Research (IJMSR). 3 (12), 2015.

Sari, Endang Kartika., Maria M. Minarsih., Edward Gagah. (2016). Analisis Pengaruh Gaya Kepemimpinan, Motivasi, Kualitas Kehidupan Kerja Terhadap 
Kinerja Karyawan (Studi Kasusu Pada PD. BKK Dempet Kabupaten Demak). Jurnal Of Management. 2 (2), Maret 2016. 